Communications in Information Literacy

Volume 10 | Issue 2

Article 6

$12-29-2016$

\title{
Designing for Engagement: Using the ADDIE Model to Integrate High-Impact Practices into an Online Information Literacy Course
}

Amanda Nichols Hess

nichols@oakland.edu

Katie Greer

greer@oakland.edu

Follow this and additional works at: https://pdxscholar.library.pdx.edu/comminfolit

Let us know how access to this document benefits you.

\section{Recommended Citation}

Nichols Hess, A., \& Greer, K. (2016). Designing for Engagement: Using the ADDIE Model to Integrate HighImpact Practices into an Online Information Literacy Course. Communications in Information Literacy, 10 (2), 264-282. https://doi.org/10.15760/comminfolit.2016.10.2.27

This open access Research Article is distributed under the terms of the Creative Commons AttributionNonCommercial-ShareAlike 4.0 International License (CC BY-NC-SA 4.0). All documents in PDXScholar should meet accessibility standards. If we can make this document more accessible to you, contact our team. 


\title{
Designing for Engagement: Using the ADDIE Model to Integrate High-Impact Practices into an Online Information Literacy Course
}

\author{
Amanda Kathryn Nichols Hess, Oakland University \\ Katie Greer, Oakland University
}

Abstract

In this article, the authors share how a team of librarians used the ADDIE instructional design model to incorporate best practices in teaching and learning into an online, fourcredit information literacy course. In this redesign process, the Association of American Colleges and Universities' high-impact practices and e-learning best practices were integrated as scaffolds for course content. The authors' experience with this systematic process and the concepts of instructional design suggest that the ADDIE model can be used to achieve several different ends in information literacy instruction. First, it can provide a structure around which librarians can develop a variety of instructional interactions.

Second, it can help librarians consider student engagement, learning, and assessment more intentionally. And third, it can help to marry information literacy-specific standards and other learning guidelines, such as high-impact practices and e-learning best practices. From the authors' experience, other academic librarians may find applications for instructional design constructs into their own teaching practices, both in online and face-to-face learning environments.

Keywords: information literacy; instructional design; online learning; ADDIE model

Nichols Hess, A.K. \& Greer, K. Designing for engagement: Using the ADDIE model to integrate high-impact practices into an online information literacy course.

Communications in Information Literacy, 10(2), 264-282.

Copyright for articles published in Communications in Information Literacy is retained by the author(s). Author(s) also extend to Communications in Information Literacy the right to redistribute this article via other scholarly resources and bibliographic databases. This extension allows the authors' copyrighted content to be included in some databases that are distributed and maintained by for-profit companies. All other rights of redistribution are licensed by Communications in Information Literacy under Creative Commons Attribution-NonCommercial-ShareAlike 4.0 International (CC BY-NC-SA 4.0). 


\section{Designing for Engagement: Using the ADDIE Model to Integrate High-Impact Practices into an Online Information Literacy Course}

\section{Introduction}

In the dynamic $21^{\text {st }}$ century information landscape, academic librarians are seeking new and innovative ways to reach learners. While partnerships with academic departments and oneshot information literacy instruction sessions are common educational activities, librarians may also engage in building and teaching credit-bearing courses that meet university graduation requirements. This extended instructional interaction with a consistent group of students offers librarians hands-on experience in instructional design, assessment, and classroom management. It also helps them to address a "richer, more complex set of core ideas" about information literacy (Association of College and Research Libraries [ACRL], 2015, Introduction) through meaningful and sustained learning opportunities.

In this article, the authors examine how they used the ADDIE instructional design framework to build an iteration of a credit-bearing information literacy course. The authors used the phases of analysis, design, development, implementation, and evaluation to integrate current e-learning best practices and several of the American Association of College and Universities' (AAC\&U) high-impact practices in an attempt to increase student engagement and make real-world applications. Through this intentional and iterative process, the authors critically reviewed course content, instructional methods, and students' learning. The authors also integrated these external best practices to "create wider conversations about student learning, the scholarship of teaching and learning, and the assessment of learning” (ACRL, 2015, Introduction), as advocated by the Association of College and Research Libraries' Framework for Information Literacy for Higher Education. This process may be useful for other librarians who teach online or face-to-face instruction in one-shot or in more extended instructional interactions.

\section{LIB250: Introduction to Library Research and Technology in the Information Age}

Oakland University (OU) Libraries offer an online four-credit course called Introduction to Library Research and Technology in the Information Age, otherwise known as LIB250. 
This course focuses on developing students' skills and dispositions needed to effectively find, ethically use, and synthesize information in the digital age. It also fulfills the writingintensive and knowledge application requirements in the university's general education curriculum, and as a result, all sections must have the same student learning outcomes. Those outcomes were built around the ACRL (2000) Information Literacy Competency Standards for Higher Education and OU's general education program. While all sections of LIB250 address information digitization, organization, creation, and ethics, the authors will show how they designed a new section of the course to bolster student engagement with the content, each other, and the instructors.

\section{Literature Review}

The authors explored three areas of the literature to inform their redesign of the LIS250 course: instructional design, a specific design model known as ADDIE, and how ADDIE had been used in academic library instruction. These areas of the existing scholarship helped to frame how they approached the course redesign process with goals of increased interdisciplinary connections and student engagement.

Instructional Design

According to Molenda, Reigeluth, and Nelson (2003), instruction design (ID) refers to "the principles and procedures by which instructional materials, lessons, and whole systems can be developed in a consistent and reliable fashion” (p. 574). Ritchey, Klein, and Tracey (2011) called ID "the science and art of creating detailed specifications for the development, evaluation, and maintenance of situations which facilitate learning and performance" (p. 3). Smith and Ragan (1999) stated that ID is "the systematic and reflective process of translating principles of learning and instruction into plans for instructional materials, activities, information resources, and evaluation" (p. 2). These three definitions address several important key points about ID as a field and approach. First, it is process-based and follows a series of steps or guidelines. This approach is referred to as a systems focus, so much so that the term "instructional systems design" is often used interchangeably with ID (Carkhuff \& Fisher, 1984; Shambaugh \& Magliaro, 2006; Sugar, 2014). Second, these processes are shaped by the overriding idea that instruction in all formats must be consistent, reliable, and effective in facilitating learning. Third, ID's systematic approach allows for evaluation and assessment of the design process and individuals' learning. 
While ID can be applied to teaching practices in any discipline, it is of growing relevance to academic librarians. As the modes, formats, and depth of academic librarians' instruction change (Shank, 2006), the design and development process they work through extends beyond the library instruction of the past. For instance, an instruction librarian may teach several sessions for the same course in a single semester (see, for instance, Loo et al., 2016); they may create and assess an assignment in partnership with subject-area faculty (see, for instance, Belanger, Bliquez, \& Mondal, 2012); or they may teach or co-teach a credit-bearing course (see, for instance, Mery, Newby, \& Peng, 2012). In addressing the myriad issues that arise in these kinds of learning scenarios, librarians may find ID processes and principles to be especially useful.

\section{The ADDIE Model}

Perhaps because of its systems focus, ID scholars have developed frameworks to create effective learning interactions. These scaffolds include Merrill's (2002) first principles of instruction, Dick and Carey's (1985) systems approach model, and Kirkpatrick's (1994) evaluation model. While these and other models provide detailed specifications for practitioners looking to systematically create and measure learning, the ADDIE instructional design framework is the most frequently used. It has five phases:

- Analyzing a learning situation;

- Designing objectives and principles to address the issues in the learning situation;

- Developing of resources to meet these specifications;

- Implementing the learning resources in the learning situation; and

- Evaluating how these resources addressed instructional needs (Branch, 2009).

The origins of this framework are unclear, and in fact Molenda (2015) concluded that ADDIE is shorthand for describing any process-based approach to developing instructional content. He also argued that the very acronym is virtually interchangeable with the term instructional design, and that many different design frameworks fall under this umbrella abbreviation. What is important about ADDIE, though, is that it is iterative, involving review and revision throughout the design process. This recursive nature is what Branch (2009) called the input-process-output paradigm. This structure allows those designing instruction to incorporate feedback throughout. 
Instructional Design and Information Literacy Instruction

Instruction librarians are increasingly adopting elements of ID, yet the literature on the use of ID models such as ADDIE is relatively sparse. Much of the scholarship is explanatory or exploratory; the research that does focus on implementing ADDIE is limited to designing one-shot, subject-based information literacy sessions or emphasizing it as a potential tool for creating a planned program of library instruction (see, for instance, Guder, 2014; Koneru, 2013; Summey \& Valenti, 2013). Easter, Bailey \& Klages (2014) provided a case study of two embedded librarians working with a faculty member to design IL modules for an online course using ADDIE; the commentary in the article from both the librarians and the faculty member provided a balanced reflection on the process and results. Davis (2013) shared her experience using the ADDIE model in consultation with her university's instructional designer to develop an IL session for journalism students in which they used library and internet resources to evaluate a librarian-created news article. Mullins (2014), dissatisfied with the ADDIE model for subject-specific IL library sessions, proposed a similar heuristic, IDEA, to address "the process for embedding information literacy instructional design within academic disciplines" (p.340).

As libraries expand their instructional activities beyond one-shot instructional sessions, the usefulness of the ADDIE model similarly broadens. Reinbold (2013) described using ADDIE to redesign three four-hour sessions embedded into an evidence-based medicine course for first-year medical students. This iterative process allowed librarians to "demonstrate both measurable results and meaningful impact in their role as educators" (Reinbold, 2013, p. 255). The ADDIE model's wide applicability and recursive nature provides for a wide variety of uses for the library, especially in projects requiring ongoing assessment and evaluation to demonstrate progression on instructional goals.

\section{Applying ADDIE to LIB250}

While other academic librarians have explored using ADDIE and other ID strategies in their teaching, the authors used this model in LIB250 to strengthen student engagement and develop cross-disciplinary conversations about students' information literacy learning. The authors used high-impact practices and current e-learning best practices to make these changes. From the outset, a systems focus guided their work (see Figure 1). This breakdown of phases and tasks was important because only one of the authors had formal training in ID. This iterative design process ensured that they, and the librarian colleagues with whom 
they collaborated at points in the process, remained focused on engagement and external best practices throughout LIB250. The systems focus also helped to break down the phases of the ADDIE model over the semesters shown in Figure 1.

\section{Figure 1 - Design System Diagram}

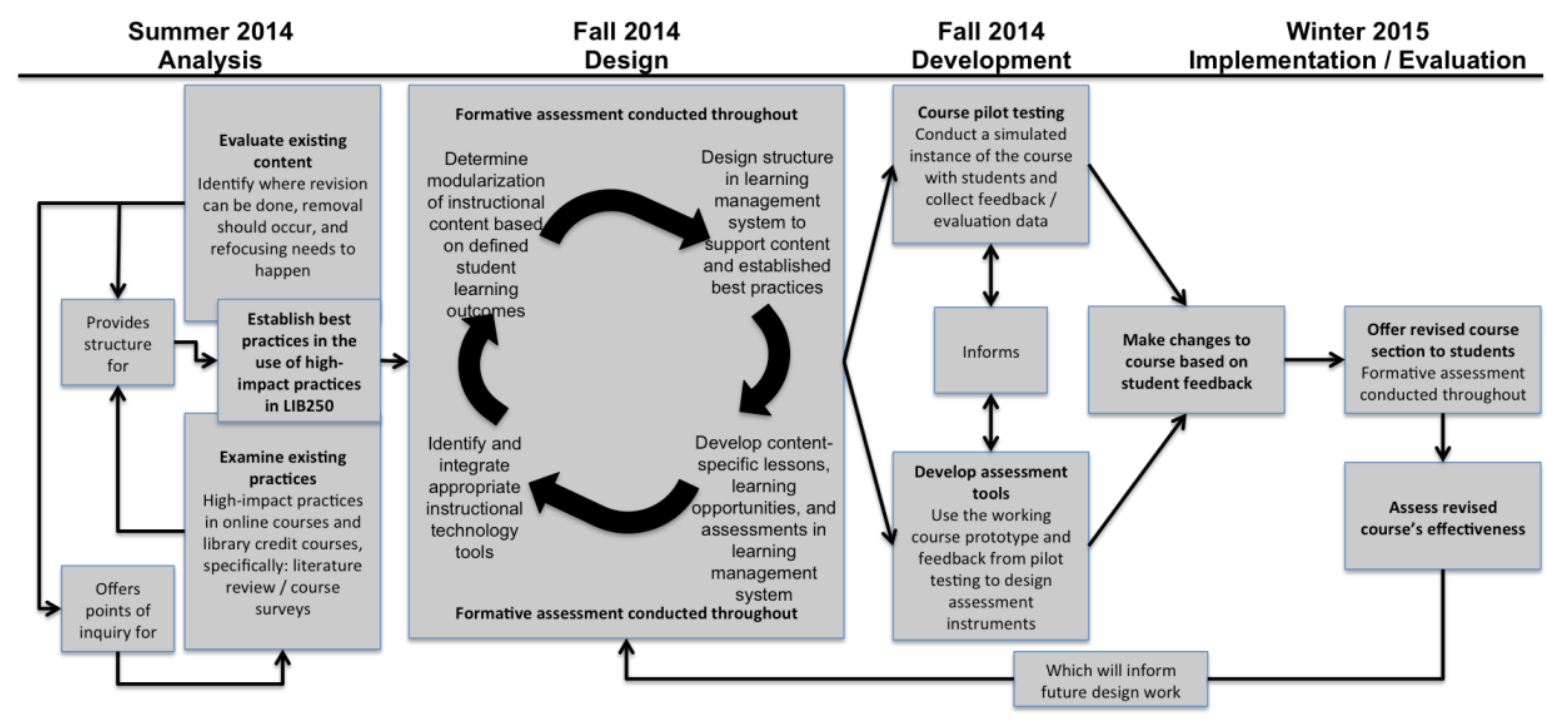

Analyzing the Instructional Issue and Learners

The analysis phase of ADDIE is initiated by an instructional issue that results in a careful look at the population of learners and their characteristics. For the authors, designing a new section of LIB250 represented a unique set of challenges. First, the course objectives were predetermined and unchangeable. Second, the course had been so successful in attracting students that additional sections had been added. Third, the existing iterations of LIB250 had attained the desired learning outcomes.

While observing sections of LIB250 taught by colleagues, the authors applied for a grant offered by OU's Center for Excellence in Teaching and Learning to implement the American Association of Colleges and Universities' (AAC\&U, 2008) high-impact practices into instruction. The authors felt these principles and current e-learning best practices could impact student engagement in LIB250 while honoring their colleagues' previous work in the course. After receiving the grant, the challenge became one of merging course content with current e-learning and high-impact practices. 
In analyzing the AAC\&U's (2008) high-impact practices, the authors identified three that could be built into LIB250. First, they ensured their course iteration was writing-intensive. According to the AAC\&U, these courses encourage students "to produce and revise various forms of writing for different audiences in different disciplines" (Writing-Intensive Courses paragraph). While LIB250 already met OU's general education standards for a writingintensive course, the authors sought ways to shift its writing tasks to assignments with realworld applicability. Second, the authors integrated collaborative tasks and assignments. Through these kinds of tasks, students learned "to work and solve problems in the company of others" and to develop knowledge "by listening seriously to the insights of others" (Collaborative Assignments and Projects paragraph). Finally, the authors identified the idea of learning communities as a scaffold to impact student engagement. While learning communities traditionally involve students enrolling in a series of courses in a sequence, the AAC\&U noted that these communities involve students considering “'big questions' that matter beyond the classroom" by exploring "a common topic and/or common readings through the lenses of different disciplines" (Learning Communities paragraph). While LIB250 was the only course offered by OU Libraries, the authors felt that the course's learning outcomes presented big questions about information that were relevant outside of the classroom and interdisciplinary in nature.

Next, the authors considered potential e-learning issues and best practices for LIB250, which attracted a wide variety of undergraduates. The authors determined that their course section could not be so technologically advanced that it would preclude transfer, nontraditional returning, first-year, or more technologically-challenged students. Still, it required newer e-learning best practices and technology tools to engage learners. To achieve these goals, the authors used Clark and Mayer's (2011) e-learning best practices. Their guidelines state that:

- Information should be segmented, or broken into manageable and cohesive parts;

- Information should be sequenced so learners have requisite background knowledge before progressing to more advanced topics;

- Words and graphics should be used together instead of using words alone;

- Words that correspond to graphics should be aligned so connections are visible;

Nichols Hess \& Greer

Designing for Engagement 
- Words should be presented as audio narration rather than as text when possible;

- Visuals should be explained through either audio or text, but not both;

- Extraneous or unnecessary information should be avoided or eliminated; and

- Conversational language and virtual "coaches" should be used as appropriate (Clark \& Mayer, 2011).

Within the authors' use of ADDIE, these standards shaped how they created LIB250 resources with their colleagues and built an overall course structure.

Designing Learning Objectives and Educational Goals

In the design phase of ADDIE, the authors and their collaborators focused on setting the objectives and principles they would use in teaching their iteration of LIB250. With all sections of LIB250 following a standard set of objectives approved by the University, the authors and their collaborators focused on scaffolding opportunities for engagement with the AAC\&U's (2008) high-impact practices.

In their review of the scholarship on writing-intensive courses, the authors and their collaborators found that students' experiences were more authentic, and that learning was more meaningful when learners wrote for multiple purposes and in multiple formats (Hall, 2014). Moreover, multiple points of feedback, both from peers (Coit, 2004; Cummings \& Barton, 2008; Kim, Mendenhall, \& Johnson 2010; Olivo, 2012) and from instructors (Laist, 2013; Warnock, 2009) were critical to developing thoughtful communicators. These feedback points should provide students with opportunities for revision while mirroring the kinds of scenarios they might encounter in their real lives (Hall, 2014; Laist, 2013). These best practices in creating writing-intensive courses illustrated how learners could engage with the content, each other, and the course instructors around writing.

As the authors and their collaborators reviewed the scholarship on facilitating engagement through collaborative tasks and assignments, the instructor's role was a central focus. This role included creating assessment mechanisms that fairly measured students' performance in group scenarios (Alden, 2011; Keengwe, Adjei-Boateng, \& Diteeyont, 2013; Williams, Cameron, \& Morgan, 2012), which was a primary roadblock for students in group work. For group work to be successful, the course instructors needed to be present. In this way, 
instructors provided information about assignment expectations, roles, and structure (Alvarez et al., 2005; Oliveira, Tinoca, \& Pereria, 2011; Williams et al., 2012); helped groups coordinate and establish norms (Lee, 2012; Thompson \& Ku, 2006); offered students opportunities to form trusting relationships (Morgan, Cameron, \& Williams, 2009; Savenye, 2005); engaged students' motivation (Beffa-Negrini, Cohen, \& Miller, 2002); and developed an overall sense of community within the online space (Liu et al., 2007; Shackelford \& Maxwell, 2012). Each of these facets of collaborative work presented ways that the authors could build increased engagement into LIB250.

Finally, designing LIB250 with the AAC\&U's (2008) notion of learning communities proved the greatest challenge. Garrison, Anderson, and Archer's (2000) community of inquiry framework, where learning happens through the interactions between students' social and cognitive presences and the instructor's presence, offered a meaningful structure for learning within smaller online learning communities. Importantly, the scholarship emphasized the importance of instructor participation in these smaller communities (Garrison et al., 2000; Murdock \& Williams, 2011). This helps online students develop connections to each other and to the content.

As they reviewed high-impact practices, the authors found that the instructor's role in the course was a central focus. In preparing to co-teach their section of LIB250, the authors identified several ways they could build in ongoing student-instructor engagement into the course. First, they would be present in the internal course learning communities to facilitate student-student and student-content engagement. Second, they would send out regular group and personal communications via email and the courseware site to remind students of deadlines and upcoming tasks. Third, they would provide virtual office hours throughout the semester for drop-in help. Additionally, they would ask students to reflect on their experiences in an anonymous mid-term course survey and address any issues identified therein.

Developing LIB250 Content

From LIB250's course objectives and these best practices, the authors developed their course iteration. They created their section's major assignments, grading rubric, syllabus, and final assignment with overall goals of impacting student engagement and integrating external educational best practices into information literacy instruction. The authors structured the course content into thematic units to better address LIB250's big ideas of information 
storage, synthesis, and ethics and to help students work toward a final project throughout the semester. By using this approach instead of a traditional week-by-week format, the authors sought to engage students more deeply with the key concepts. To replace a formal research paper, they designed a final assignment that required students to build a multi-page online research guide. This task integrated writing in different, but meaningful ways, while also engaging students with contemporary information use and creation.

The authors weaved new information into existing units from previous LIB250 sections to create chunked, interactive lessons, following Clark and Mayer's (2011) e-learning best practices. They also designed systems to help students interact with each other and with the instructors as they worked with the course content. They constructed four communities of six learners within the course that remained consistent throughout the semester. One of the authors was included in each of these communities to facilitate inter-student and studentinstructor interaction. Within the course communities, the authors created a variety of whole and small-group collaborative assignments.

Once they built the course structure and content, the authors sought feedback from representative learners on their iteration of LIB250. In an IRB-approved study, the authors and their collaborators asked participants $(n=4)$ to pilot test the course while their screen movements and voices were recorded. All participants examined the syllabus, course rubrics, and the introductory module; they were then each assigned a thematic module to work through. Following their review, each participant completed an online survey about the course content and a feedback form about their experiences.

Overall, feedback on the course was positive. Participants offered praise for LIB250's detailed expectations, extensive rubrics, and final project. While much of the participants' feedback focused on mechanics and bug fixes, they did provide constructive criticism on how the course's content was presented. For example, several students appreciated the use of screenshots and other media to illustrate the information. They noted pages that were too text-heavy; one student stated that she preferred having a video to reinforce or replicate textual content. Participants also commented positively about the setup of the small learning communities and collaborative assignments. They felt these structures provided opportunities to connect with their classmates and professors as they would in a face-to-face classroom. 
Although the participants' feedback was not extensive, the pilot test of the course material did lead to a major change. Participants commented that the content in the course units felt repetitive and haphazard: Some focused on content types, and others focused on research behaviors. As a result, the authors restructured these units to present a unified approach to research that showed how different information types fit into a larger picture of information literacy (see Table 1).

Table 1 - Unit Themes Before and After Pilot Testing

\begin{tabular}{|l|l|}
\hline Initial redesign units & Units after pilot testing \\
\hline Introduction to LIB250 $\rightarrow$ & Introduction to LIB250 (1 week) \\
\hline The Information Age $\rightarrow$ & Introduction to the Information Age \\
\hline Information Sources $\rightarrow$ & Starting Your Research \\
\hline The Open Web $\rightarrow$ & Expanding and Focusing Your Research \\
\hline The Research Process $\rightarrow$ & $\begin{array}{l}\text { Looking Forward \& Course Conclusion (1 } \\
\text { week) }\end{array}$ \\
\hline
\end{tabular}

Student feedback during the development process also led to smaller instructional changes. For instance, the teaching team clarified quiz questions, made important links/readings more explicit, and created a sample final project for students to review. Since they arose directly from representative learners' feedback, the authors incorporated these modifications to impact student engagement in the course.

Implementing LIB250

Following the pilot testing, the authors taught their new iteration of LIB250 to a group of 24 students. Although implementation represents an independent and discrete phase in the ADDIE model, the authors continually analyzed, designed, developed, and evaluated the course as it was offered. As noted, the course followed a unit structure, and activities within each unit were consistent (see Figure 2). During the first week of each unit, students worked through a chunked lesson and participated in discussions within their learning communities. This forum required students to grapple with the unit's issues and to consider others' perspectives.

In the second week of each unit, students worked through a content lesson and then engaged in team tasks within their learning communities; this helped them to build understanding about ideas, topics, or resources. Based on the best practices for collaborative 
work, the authors constructed tasks so students were only graded on their own work. Most team tasks started with an individual completing a component of the task and submitting his or her work to the group. In response, the other group members commented on each other's work, or the group combined their parts to complete a larger assignment.

\section{Figure 2 - Screenshot of a Thematic Unit}

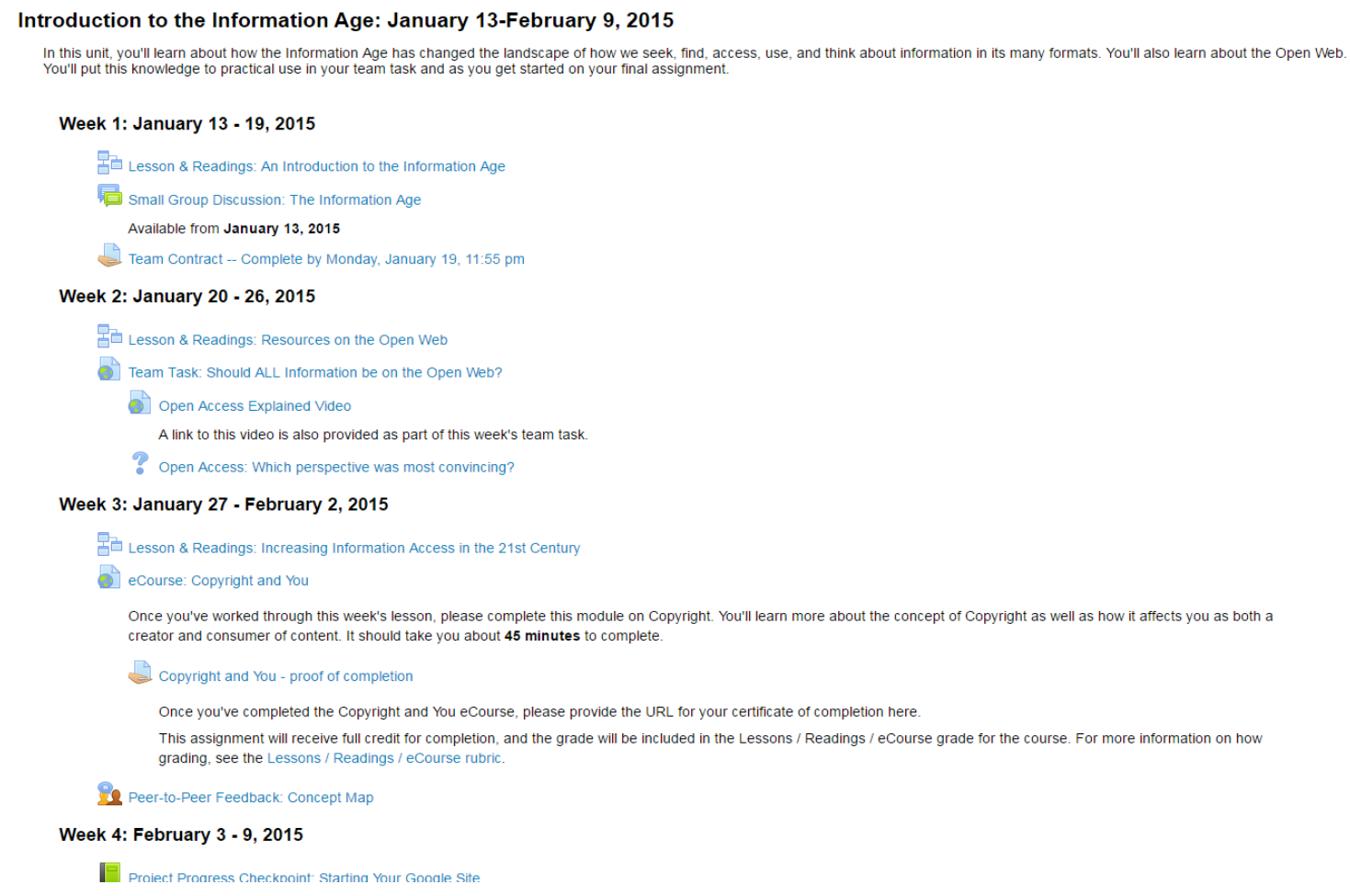

In the third week of each unit, students completed a lesson and then participated in peer-topeer feedback workshops focused on developing content for the final course assignment. Students submitted a draft of part of the final project and were randomly assigned to a peer with whom they exchanged constructive feedback. As with the other collaborative activities, this task was designed so students could consider a variety of perspectives about the unit's content, solve problems in different ways, and develop their own understandings of the key course ideas. In the fourth week of each unit, students worked through any supplementary/concluding readings, submitted a draft of a piece of their final project for instructor feedback, and reflected on their learning experience in a journal shared with the 
authors. In answering these questions, learners reflected on and assessed their unit performance.

Course units built to a final assignment, a multi-page online research guide (a sample project may be viewed at https://sites.google.com/a/oakland.edu/amanda-hess-lib250-researchguide/). In this project, students applied the key course ideas in researching a topic of their choice and creating an educational resource for others.

\section{Evaluating LIB250}

Although course assessment represents a single component of the ADDIE framework, the authors constantly assessed their course development and implementation, identified where gaps existed, and determined what issues still needed to be addressed. Once the new section of LIB250 was implemented, the authors sought to measure the impact of the design process on student engagement.

Students' engagement with content, classmates, and the instructor represent affective facets of learning that are difficult to quantify. Initially, the authors had hoped to compare their iteration of LIB250 to past sections of the course; however, the content and the structure proved so different that making this comparison would have been inconsistent. For this reason, the authors used formative and summative assessment strategies within the course.

Formative, or in-process assessment was used to ensure learners were engaging with course concepts to meet learning objectives. For example, the authors noticed at the end of the first unit that students were not grasping some of the important ideas that would build in subsequent units. To address this, the authors reviewed all performance data, identified where points of confusion occurred, and created an end-of-unit wrap-up reading. This targeted the specific ideas or concepts that were difficult for students, and the unit wrap-up was integrated into each of the course's subsequent units. The authors also engaged in more structured formative evaluation through regular student-instructor communication. They sent personal email messages to all students, regardless of performance, to gain their insight into how the course was going. This was a way to engage with students, and it was a tool to identify areas where the authors could better meet learners' needs.

To measure student engagement within the course, the authors created and distributed an anonymous mid-course evaluation. Learners were asked to reflect on what was impactful to their learning and what tasks, concepts, or course structures impeded their progress. 
Twenty-three of 24 students responded, and from their comments, the instructors identified ways to improve engagement with content, each other, and instructors. The small learning community group assignments were very well-received; students commented that these tasks made them feel connected to teammates and course content. However, some tasks were singled out as being more effective than the others. The authors used these remarks to identify where and how engagement occurred, for both content and learner interaction, and they revised future assignments accordingly.

The authors used the final course assignment for summative evaluation. In reviewing students' final projects, the authors gained insight into overall engagement with course concepts and the assignments that either facilitated or failed to facilitate desired levels of engagement. For instance, source analysis was used to inform future iterations of LIB250 and the unit on primary and secondary sources. In contrast, however, the authors noted that grounding the final project in real world application-including the intended audience requirement- engaged learners with the course's information literacy concepts in concrete and cross-disciplinary ways. The summative work of students, then, provided useful overall insight into the LIB250. Furthermore, the authors gained direction for structuring future sections of LIB250 to facilitate student engagement, enhance student learning, and integrate information literacy concepts more deeply into other disciplines.

\section{Conclusions and Future Applications}

The authors used the ADDIE instructional design model in this case study to create a section of a four-credit, online information literacy course. This design process focused on engaging students with the course content, each other, and the instructors in innovative ways.

Lessons learned in this process can be applied to other instructional undertakings where student engagement is a central concern. Employing a systematic approach in the design and evaluation process provided a blueprint for the project that lent clarity and a strategic focus throughout. Relying on the scholarly and professional literature in the analysis and design phases helped to focus and refine the authors' efforts and created a scaffold around which they could then build engaging instructional content and learning experiences.

While the authors and their colleagues used the ADDIE framework to facilitate student engagement in a credit-bearing course, this structure might be used by librarians in a variety of instructional situations. This process can be scaled down to fit smaller or more discrete 
instructional needs because a systematic design process that incorporates feedback is essential to designing meaningful learning opportunities. For those designing credit-bearing courses, engaging intended learners in pilot testing can help course designers to make a more intentionally designed and engaging learning experience. For those who are working to create effective single instructional interactions, student engagement is equally critical to meaningful learning. Additionally, for instructors creating more extended learning interactions, this case has shown that ongoing feedback can make the learning experience more meaningful and significant.

Finally, the Framework for Information Literacy for Higher Education (2015) asks academic librarians to reconsider what information literacy means and what teaching it looks like. At a basic level, applying a systems-focused design process such as the ADDIE model to create these new learning interactions may help to clarify how librarians and learners alike can address the new information literacy frames. As librarians integrate these frames into their teaching, they may also find that a systems focus can help to create or extend conversations with disciplinary faculty about what information literacy means to them. In considering how to scale this particular application of the ADDIE model, librarians might also evaluate how they can integrate discipline-specific or other educational standards into their teaching. Such integration might push the boundaries of information literacy instruction. 


\section{References}

American Association of Colleges and Universities [AAC\&U]. (2008). High-impact practices: A brief overview. Retrieved from http://www.aacu.org/leap/hips

Association of College and Research Libraries. (2015, February 2). Framework for Information Literacy for Higher Education. Retrieved from http://www.ala.org/acrl/standards/ilframework

Alden, J. (2011). Assessment of individual student performance in online team projects. Journal of Asynchronous Learning Networks, 15(3), 5-20.

Alvarez, D. M., Blair, K., Monske, E., \& Wolf, A. (2005). Team models in online course development: A unit-specific approach. Journal of Educational Technology \& Society, 8(3), 176-186.

Beffa-Negrini, P. A., Cohen, N. L., \& Miller, B. (2002). Strategies to motivate students in online learning environments. Journal of Nutrition Education and Behavior, 34(6), 334-340.

Belanger, J., Bliquez, R., \& Mondal, S. (2012). Developing a collaborative faculty-librarian information literacy assessment project. Library Review, 61(2), 68-91.

Branch, R. M. (2009). Instructional Design: The ADDIE model. New York: Springer

Carkhuff, R. R. \& Fisher, S. G. (1984) ISD, Instructional systems design. Amherst, MA: Human Resource Development Press.

Clark, R. C. \& Mayer, R. E. (2011). e-Learning and the Science of Instruction. New York: Pfeiffer.

Coit, C. (2004). Peer review in an online college writing course. Proceedings of the IEEE Conference on Advanced Learning Technologies. Joensuu, 30 August-1 September, 2004. Piscataway: Institute of Electrical and Electronics Engineers.

Cummings, R. E. \& Barton, M. (2008). Wiki writing: Collaborative learning in the college classroom. Ann Arbor, MI: Digital Culture Books. 
Davis, A. L. (2013). Using instructional design principles to develop effective information literacy instruction. College \& Research Libraries News, 74(4), 205-207.

Dick, W. \& Carey, L. (1985). The systematic design of instruction (2nd ed.). Glenview, IL: Scott, Foresman.

Easter, J., Bailey, S., \& Klages, G. (2014). Faculty and librarians unite! How two librarians and one faculty member developed an information literacy strategy for distance education students. Journal of Library \& Information Services in Distance Learning, 8, 242262.

Garrison, D. R., Anderson, T., \& Archer, W. (2000). Critical inquiry in a text-based environment: Computer conferencing in higher education. The Internet and Higher Education, 2(2), 87-105.

Guder, C. (2014). Modifying ADDIE: Incorporating new technologies in library instruction. Public Services Quarterly, 10(2), 138-149.

Hall, M. (2014, February 18). Rethinking student writing assignments. [Web log post]. Retrieved from http://ii.library.jhu.edu/2014/02/18/rethinking-student-writingassignments/

Keengwe, J., Adjei-Boateng, E., \& Diteeyont, W. (2013). Facilitating active social presence and meaningful interactions in online learning. Education and Information Technologies, 18(4), 597-607.

Kim, C., Mendenhall, A., \& Johnson, T. E. (2010). A design framework for an online English writing course. In J.M. Spector, D. Ifenthaler, P. Isais, Kinshuk, \& D. Sampson (Eds.), Learning and instruction in the digital age (pp. 345-360). Boston, MA: Springer US.

Kirkpatrick, D. L. (1994). Evaluating training programs: The four levels. San Francisco: BerrettKoehler.

Koneru, I. (2010). ADDIE: Designing web-enabled information literacy instruction modules. Journal of Library \& Information Technology, 30(3), 23-34.

Laist, R. (2013). Five ways a blog-style assignment can jump-start student writing. Teaching English in the Two-Year College, 41(1), 75-76. 
Lee, J. (2012). Patterns of interaction and participation in a large online course: Strategies for fostering sustainable discussion. Educational Technology \& Society, 15(1), 260-272.

Loo, J. L., Eifler, D., Smith, E., Pendse, L., He, J., Sholinbeck, M., . . Dupuis, E. A. (2016). Flipped instruction for information literacy: Five instructional cases of academic librarians. Journal of Academic Librarianship, 42(3), 273-280.

Merrill, M. D. (2002). First principles of instruction. Educational Technology Research and Development, 50(3), 43-59.

Mery, Y., Newby, J., \& Peng, K. (2012). Why one-shot information literacy sessions are not the future of instruction: A case for online credit courses. College \& Research Libraries, 73(4), 366-377.

Molenda, M. (2015). In search of the elusive ADDIE model. Performance Improvement, 54(2), 40-42.

Molenda, M., Reigeluth, C. M., \& Nelson, L. M. (2003). Instructional design. In L. Nadel (Ed.), Encyclopedia of Cognitive Science, Hoboken, NJ: Wiley. Retrieved from http://search.credoreference.com/content/entry/wileycs/instructional_design/0

Morgan, K., Cameron, B. A., \& Williams, K. C. (2009). Student perceptions of social task development in online group project work. Quarterly Review of Distance Education, 10(3), 285-294.

Mullins, K. (2014). Good IDEA: instructional design model for integrating information literacy. Journal of Academic Librarianship, 40(3), 339-349.

Murdock, J. L. \& Williams, A. M. (2011). Creating an online learning community: Is it possible? Innovative Higher Education, 36(5), 305-315.

Oliveira, I., Tinoca, L., \& Pereira, A. (2011). Online group work patterns: How to promote a successful collaboration. Computers \& Education, 57(1), 1348-1357.

Olivo, R. F. (2012). Collaborative online writing assignments to foster active learning. Journal of Undergraduate Neuroscience Education, 11(1), A82-A89.

Reinbold, S. (2013). Using the ADDIE model in designing library instruction. Medical Reference Services Quarterly, 32(3), 244-256. 
Ritchey, R., Klein, J., \& Tracey, M. W. (2011). The instructional design knowledge base: Theory, research, and practice. New York: Routledge.

Savenye, W. C. (2005). Improving online courses: What is interaction and why use it? Distance Learning, 2(6), 22-28.

Shackelford, J. L. \& Maxwell, M. (2012). Sense of community in graduate online education: Contribution of learner to learner interaction. International Review of Research in Open and Distance Learning, 13(4), 228-249.

Shambaugh, R. N. \& Magliaro, S. (2006). Instructional design: A systematic approach for reflective practice. Boston: Pearson.

Shank, J. D. (2006). The blended librarian: A job announcement analysis of the newly emerging position of instructional design librarian. College \& Research Libraries, 67(6), 515-524.

Smith, P. L. \& Ragan, T. J. (2005). Instructional Design (3rd Ed.). New York: Wiley.

Sugar, W. (2014). Studies on instructional design practices: Current practices and lessons learned. New York: Springer.

Summey, T. P., \& Valenti, S. (2013). But we don't have an instructional designer: Designing online library instruction using ISD techniques. Journal of Library \& Information Services in Distance Learning, 7(1-2), 169-182.

Thompson, L. \& Ku, H. (2006). A case study of online collaborative learning. Quarterly Review of Distance Education, 7(4), 361-375.

Warnock, S. 2009. Teaching writing online: How and why. Urbana: National Council of Teachers of English.

Williams, K. C., Cameron, B. A., \& Morgan, K. (2012). Supporting online group projects. NACTA Journal, 56(2), 15-20. 